\title{
Correlates of Body Composition and Nutritional Status of 9-12 Year Old School Going Children in Kochi
}

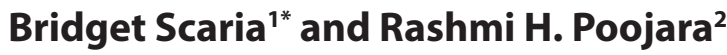 \\ 'Former PG Student, Department of Home Science, St Teresa's College, Ernakulam, Kerala, India \\ ${ }^{2}$ Assistant Professor, Department of Home Science, St Teresa's College, Ernakulam, Kerala, India; \\ rashmipoojara@rediffmail.com
}

\begin{abstract}
Assessment of body composition is important in the management of many illnesses as well as in the assessment of nutritional status. Human body composition varies widely from one population to another, as age related patterns of changes in body size and composition differ among populations. The study was conducted in 63 urban children of age 9-12 years from two schools in Ernakulam District, Kerala by purposive sampling method. Interview schedule was used for data collection. Anthropometric parameters of the subjects namely weight, height, body mass index, mid upper arm circumference, waist and hip circumference, waist hip ratio, sum of skin fold thickness were taken. Body composition was computed by two equations namely Mcardle et al and Deurenberg predictive equations. The collected data was analyzed by appropriate statistical analysis. On classifying the subjects according to BMI percentiles it was observed that 17.9 per cent of boys and 8.4 per cent of girls belong to the underweight, 10.3 per cent and 20.8 per cent of boys and girls were overweight respectively. The remaining had a normal BMI. The body fat per cent calculated using Deurenberg Predictive equation (1991) was 16.4 percent in boys and 20.4 percent in girls and by McArdle Predictive equations (1986) was 15.9 percent in boys and 16.8 percent in girls. On studying Pearson's correlation of anthropometric parameters with per cent body fat it was evident that there exists a positive correlation $(\mathrm{P}<.01)$ between all the anthropometric parameters and per cent body fat, indicating that there is an increase in the anthropometric dimensions of an individual. On studying, Pearson's correlation between SSFT and anthropometric parameters, it was evident that there exists a positive correlation $(\mathrm{P}<.01)$ between all the anthropometric parameters indicating increased subcutaneous fat. On studying the Pearson's correlation of nutrient intake with per cent body fat and fat mass, it was found that there was no significant correlation between these parameters. The findings provide a picture of the correlates of body composition and nutritional status of school going children aged 9-12 years.
\end{abstract}

Keywords: Body Composition, Deurenberg Predictive Equation, Mcardle Equation, Nutritional Status

\section{Introduction}

The school age period has been called the latent period of growth. During this period the rate of growth slows and body changes occur gradually. School age group (5-18years) spans the period between preschool years and adult life [1].The growth rate slightly slow down and dietary habit is formed and fixed during the school age, which is thus greatly affected by stimuli through school life and peer groups [2].

Measures of body composition and total body fatness change with growing, developing and ageing. Specific cut off values for children and adolescents have been suggested based on specific health-related criteria. However, defining obesity standards in children and adolescents remains controversial and widely accepted

${ }^{*}$ Author for correspondence 
per cent body fat $(\% \mathrm{BF})$ criteria have developed. Several studies reported the relationship between adiposity and metabolic risk factors in children and adolescents [3].

Assessment of body composition is important in the management of many illnesses as well as in the assessment of nutritional status. In certain instances weight gain of an individual may be due to weight gain in one component of the body that is, only in Fat Mass (FM) but not in Fat Free Mass (FFM). Human body composition varies widely from one population to another, as age related patterns of changes in body size and composition differ among population [4]. Assessment of body composition is important since it is known that many disease and disorders are related to abnormal body composition.

Therefore understanding specifically the changes in various body components accurately is important in managing certain illnesses. However, in order to achieve this, the use of sophisticated equipment for the direct measures of body fat, is time consuming, need expensive equipment with trained staff and could be cumbersome to subjects especially children. These methods are not practical to use in low income countries with high population. A rapid non-invasive, less expensive and portable procedure such as anthropometric measurements would be much useful. Height and weight or BMI based equations would be very simple to use. If such techniques could assess body composition with reasonable accuracy, it would be useful for the management of patients in low income countries. Height weight based predictive equations namely Deurenberg predictive equation [5] skin fold thickness based equations by McArdle [6] can be good predictors of body composition.

The present study was thus undertaken with the broad objective of eliciting information regarding correlates of body composition and nutritional status among nine to twelve year old school going children in Kochi.

The specific objectives of the present study include:-

- To assess the nutritional status of school children aged 9-12 years in Kochi.

- To determine the body composition of the selected subjects using Deurenberg and Mcardle predictive equations.

- To assess the correlation between body composition anthropometric indices, biochemical measurements and dietary intake.

\section{Materials and Methods}

\subsection{Selection of Area}

Nutritional transition is used to categorise the shift in disease patterns towards nutrition related communicable diseases. This shift in disease patterns is associated with change in behaviour, lifestyles, diet and physical activity. The rapidity of such nutritional transition is clearly visible in emerging nations from Asia [7]. There is evidence of such a rapid nutritional transition amplifying the burden of chronic diseases and obesity in India [8]. The newly rich urban middle and high income population in Cochin City suffer from an emerging problem of obesity due to changing lifestyle and diet. Therefore, Cochin Corporation was selected as the area for the study. The study population included sixty three urban children of the age group 9-12years from two schools in Ernakulam District, Kerala. The subjects were categorized by various grades of nutritional status using BMI -Age/Sex percentiles (Table 1). The two urban schools were selected by purposive sampling. The sub sampling was formed by voluntary presentation for a blood draw in the prescribed age group after dissemination of study information. Children with systemic illness or on medication were not included in the sub sampling. Schedule method was employed for data collection. It is a proforma containing a set of questions and tables, which include both open ended and close ended questions. These include socioeconomic background, dietary habits and 24 hour dietary recall of three consecutive days (two working days and one holiday) of the subjects.

To assess the overall nutritional status of the subjects, anthropometric measurements which include height, weight, waist and hip circumference, MUAC,BMI,WHR were taken. body fat percentage was computed using Deurenberg equation [5] and McArdle et al. [6] equation respectively.

Table 1. Nutritional grades using BMI percentiles

\begin{tabular}{|c|c|}
\hline BMI percentiles & Nutritional Grades \\
\hline$<5^{\text {th }}$ percentile & Under nutrition \\
\hline$\geq 5^{\text {th }}-<85^{\text {th }}$ percentile & Normal \\
\hline$\geq 85^{\text {th }}-<95^{\text {th }}$ percentile & Overweight \\
\hline$\geq 95^{\text {th }}$ percentile & Obesity \\
\hline
\end{tabular}

Source: NHANES (2005) 


\subsection{Body Composition}

The assessment of body composition is important in the management of much illness as well as in the assessment of nutritional status.

In the present study, body composition was computed using both the predictive equations namely Deurenberg [5] and McArdle et al [6].

Body Fat percentage by Deurenberg equation

Deurenberg et al [5] studied 1229 subjects between the age range of 7-83 years and determined body composition by densitometry and anthropometry. Based on the results obtained, height, weight based predictive equation were developed to compute body fat. BMI taking age and sex (males-1, females- 0) into account was analysed. These predictive equations are used in the present study and are listed as shown below:

Body Fat $(\%)=(1.51 \mathrm{X}$ BMI $)-(0.70 \mathrm{X}$ Age $)-$ $(3.6 \mathrm{XGender})+1.4$

McArdle equation using Skin folds measurements

McArdle et al [6] studied body fat per cent on healthy boys and girls of 11-20 years, by measuring the skin fold thickness. A Langes calliper was used. Three to five replicate measurements were taken on the right side of the body with subjects standing. The skin fold thickness was measured to the nearest $\mathrm{mm}$.

Thus body composition is measured using sum of skin fold thickness, in the equation formulated by McArdle et al:

$$
\text { Body Fat }(\%)=0.55(\text { Triceps }(\mathrm{mm}))+6.13
$$

\subsection{Biochemical Assessment}

Biochemical assessment deals with the measuring of the level of essential dietary constituents in the body fluids (blood and urine) which is helpful in evaluating the possibility of malnutrition. Biochemical tests were adopted for BP, Insulin, FBS, Lipid profile, ApolipoproteinA1\&B, $\mathrm{C}$ - reactive protein (CRP).

\subsection{Dietary Intake}

A diet survey provides information about the dietary intake pattern of specific foods consumed and helps to estimate nutrient intakes. Dietary survey constitutes an essential part of complete study of nutritional status of individuals or food habits, nutrient intake, source of nutrients etc.

\subsubsection{Hour Dietary Recall}

24 hour dietary recall method is probably the most widely used method of dietary assessment. In this method, the individual is asked to recall with as much detail as possible, the food intake for the past 24 hours by using a questionnaire. This was adopted for three days namely two working days and one holiday. The respondent recalls what was eaten, how the foods were prepared, when it was eaten and other relevant details related to food intake. For all preparations made for each meal the ingredients used are first listed. The mothers are then asked to give the actual weights of each of the food ingredients used in each preparation. This will give the quantity of total raw food used for the family and the total cooked quantity for each food item was also taken so that individual raw intake was calculated.

Using standardized recipe, standardization of commonly consumed diet were done and using standardized results nutrient composition was calculated. From the 24 hour dietary recall, the nutrient composition of the diet were calculated for three consecutive days, using NIN nutritive values (by ICMR) and USDA values (National Nutrient Database, Release 22, August 11, 2009). The nutrient composition of standardized recipes was also used to arrive at the actual nutrient intake of subjects.

\section{Analysis and Interpretation of Data}

The data obtained from the study was subjected to appropriate statistical analysis (SPSS 11.0 version). Values are given as means and standard deviation. Pearson's Correlation coefficient was used to assess the relationship between anthropometric parameters, body composition and nutrient intake. All the data was approximately interpreted and is presented in the next section of the study.

\section{Results and Discussion}

\subsection{General Background Information of Subjects}

The data revealed that among 63 subjects selected for the study, 21 per cent belonged to nine years and ten years, 30 per cent belong to eleven years and 28 per cent 
belonged to twelve years of age. Overall, 62 per cent of the subjects were boys and were 38 per cent girls. On studying the education of head of the family nearly half of them were graduates and one third had education up to the Diploma or Intermediate level.

Approximately, three fourth of the subjects belonged to upper middle class and 11 percent belonged to lower middle class. A vast majority of the subjects belonged to nuclear family ( 84 per cent) and only 16 per cent belonged to joint family. Majority of the subjects were Hindus ( 83 per cent), 14 per cent and three per cent were Christians and Muslims respectively.

\subsection{Anthropometric Characteristics of Subjects}

Anthropometric parameters of the subjects namely height, weight, body mass index, mid upper arm circumference, waist and hip circumference, waist hip ratio, sum of skin folds and body fat percentage are presented in the Tables 2 to 12 .

Table 2. Weight for age of boys $(n=39)$

\begin{tabular}{|c|c|c|c|c|}
\hline Age (in years) & $\mathbf{n}$ & Mean \pm SD $(\mathbf{K g})$ & $\begin{array}{c}\text { NCHS }^{*} \text { standard } \\
(\mathbf{K g})\end{array}$ & $\begin{array}{c}\text { \%NCHS } \\
\text { standard }\end{array}$ \\
\hline 9 & 6 & $26.7 \pm 3.5$ & 29.7 & 90 \\
\hline 10 & 9 & $34.2 \pm 10.1$ & 33.3 & 103 \\
\hline 11 & 11 & $32.8 \pm 6.6$ & 37.5 & 87 \\
\hline 12 & 13 & $44.2 \pm 10.1$ & 42.3 & 104 \\
\hline
\end{tabular}

*NCHS- National Center for Health Statistics (2004)

On studying mean weight-for-age of boys it was observed that weight was at par with NCHS standards in the range of 87 to 104 per cent respectively.

Table 3. Weight for age of girls $(\mathrm{n}=24)$

\begin{tabular}{|c|c|c|c|c|}
\hline Age (in years) & $\mathbf{N}$ & Mean \pm SD $(\mathbf{K g})$ & $\begin{array}{c}\mathbf{N C H S}^{*} \text { standard } \\
(\mathbf{K g})\end{array}$ & $\begin{array}{c}\text { \% NCHS } \\
\text { standard }\end{array}$ \\
\hline 9 & 7 & $34.6 \pm 8.4$ & 30.5 & 113 \\
\hline 10 & 4 & $31.4 \pm 1.6$ & 34.7 & 90 \\
\hline 11 & 8 & $34.8 \pm 9.2$ & 39.2 & 89 \\
\hline 12 & 5 & $45.7 \pm 15.1$ & 43.8 & 104 \\
\hline
\end{tabular}

"NCHS- National Centre for Health Statistics (2004)

The mean weight of the subjects ranged from 89 to 113 per cent of the NCHS standard weight, with the lowest among eleven year olds and highest among the nine year olds.
Table 4. Height for age of boys $(n=39)$

\begin{tabular}{|c|c|c|c|c|}
\hline Age (in years) & $\mathbf{N}$ & Mean \pm SD $(\mathbf{K g})$ & $\begin{array}{c}\text { NCHS } \\
(\mathbf{c m})\end{array}$ & $\begin{array}{c}\text { standard } \\
\text { standard }\end{array}$ \\
\hline 9 & 6 & $135 \pm 8.02$ & 134.8 & 100 \\
\hline 10 & 9 & $139.3 \pm 5.8$ & 140.3 & 99 \\
\hline 11 & 11 & $140.1 \pm 8.9$ & 146.4 & 96 \\
\hline 12 & 13 & $150.5 \pm 10$ & 153.0 & 98 \\
\hline
\end{tabular}

"NCHS- National Centre for Health Statistics (2004)

On studying mean height-for-age of boys it was observed that height was in par with NCHS standards in the range of 96 to 100 per cent respectively for all age groups.

Table 5. Height for age of girls $(n=24)$

\begin{tabular}{|c|c|c|c|c|}
\hline $\begin{array}{c}\text { Age } \\
\text { (in years) }\end{array}$ & $\mathbf{N}$ & $\begin{array}{c}\text { Mean } \pm \text { SD } \\
(\mathbf{c m})\end{array}$ & $\begin{array}{c}\text { NCHS }^{*} \\
\text { standard (cm) }\end{array}$ & $\begin{array}{c}\text { \%NCHS } \\
\text { standard }\end{array}$ \\
\hline 9 & 7 & $137 \pm 7.6$ & 135.2 & 101 \\
\hline 10 & 4 & $137 \pm 5.6$ & 141.5 & 97 \\
\hline 11 & 8 & $143 \pm 10.4$ & 148.2 & 96 \\
\hline 12 & 5 & $153.9 \pm 5.9$ & 154.6 & 99 \\
\hline
\end{tabular}

"NCHS- National Centre for Health Statistics (2004)

The mean height of the subjects ranged from 96 to 101 per cent of the NCHS standard height, with the lowest among eleven year olds and highest among the nine year olds.

Overall the height and weight profile of subjects of all age groups were in par with NCHS standards indicating no gross deficit/excess in their anthropometric parameters.

Table 6. Body mass index profile of subjects $(n=63)$

\begin{tabular}{|c|c|c|c|}
\hline Age (in years) & Sex & N & BMI $\left(\mathbf{k g} / \mathbf{m}^{2}\right)$ Mean \pm SD \\
\hline \multirow{2}{*}{9} & Boys & 6 & $15.3 \pm 2.0$ \\
& Girls & 7 & $17.9 \pm 3.3$ \\
\hline \multirow{2}{*}{10} & Boys & 9 & $17.5 \pm 4.5$ \\
& Girls & 4 & $16.8 \pm 2.1$ \\
\hline \multirow{2}{*}{11} & Boys & 11 & $16.5 \pm 2.6$ \\
& Girls & 8 & $16.7 \pm 2.6$ \\
\hline \multirow{2}{*}{12} & Boys & 13 & $19.3 \pm 2.8$ \\
& Girls & 5 & $19.0 \pm 5.1$ \\
\hline
\end{tabular}

The above table presents the BMI of the subjects segregated by age and gender. On studying the Body Mass Index (BMI) of the subjects it was found that there was a slight increase among the girls as compared to boys. The body mass index of the subjects was in the range of 15.3$19.3 \mathrm{~kg} / \mathrm{m}^{2}$. 
A cross sectional national survey conducted by Musaiger [9], to study the body composition of Bahraini school children aged 6-18 year found that BMI varies significantly by age and sex, the trend of increasing of BMI by age is similar, expect that sex difference is evident earlier. Girls have higher mean BMI at all ages except at ages nine and eighteen years, where the BMI is comparable in both sexes.

Table 7. Classification of subjects by BMI percentile* $(\mathrm{n}=63)$

\begin{tabular}{|c|c|c|c|c|}
\hline \multirow{2}{*}{ Category } & \multicolumn{2}{|c|}{ Boys } & \multicolumn{2}{c|}{ Girls } \\
\cline { 2 - 5 } & $\mathbf{N}$ & Percent & N & Percent \\
\hline Underweight & 7 & 17.9 & 2 & 8.4 \\
\hline Normal & 28 & 71.8 & 17 & 70.8 \\
\hline Overweight & 4 & 10.3 & 5 & 20.8 \\
\hline
\end{tabular}

NHANES (2005)

Table 8. MUAC, waist, hip, WHR measurements of subjects $(\mathrm{n}=63)$

\begin{tabular}{|c|c|c|c|c|c|}
\hline Age & $\mathbf{n}$ & $\begin{array}{c}\text { MUAC } \\
\text { Mean } \pm \text { SD }\end{array}$ & $\begin{array}{c}\mathbf{W C}^{\star}(\mathrm{cm}) \\
\text { Mean } \pm \text { SD }\end{array}$ & $\begin{array}{c}\mathbf{H C}^{\star}(\mathbf{c m}) \\
\text { Mean } \pm \text { SD }\end{array}$ & $\begin{array}{c}\text { WHR }^{*} \\
\text { Mean } \pm \text { SD }\end{array}$ \\
\hline 9 & 6 & $26.7 \pm 3.5$ & 29.7 & 90 & $0.85 \pm .04$ \\
\hline 10 & 9 & $34.2 \pm 10.1$ & 33.3 & 103 & $0.85 \pm .06$ \\
\hline 11 & 11 & $32.8 \pm 6.6$ & 37.5 & 87 & $0.85 \pm 0.03$ \\
\hline 12 & 13 & $44.2 \pm 10.1$ & 42.3 & 104 & $0.86 \pm 0.06$ \\
\hline
\end{tabular}

*MUAC- Mid upper arm circumference, ${ }^{*}$ WC- Waist circumference, ${ }^{*} \mathrm{HC}$ Hip circumference, ${ }^{\star}$ WHR- Waist-Hip ratio

On classifying the subjects according to BMI percentiles it was observed that 17.9 per cent of boys and 8.4 per cent of girls belong to the underweight, 10.3 per cent and 20.8 per cent of boys and girls are in overweight category respectively. The remaining had a normal BMI.

Shah et al [10] conducted a cross sectional randomized epidemiological study among children; children aged 8-12 years regarding assessment of obesity and factors affecting it. The study reported that the overall prevalence of overweight and obesity is higher in girls as compared to boys. Similar findings were observed in the present study too.

On studying the MUAC, WC, HC and WHR measurements of the subjects, it was found that there was a progressive increase from 19 to $23.3 \mathrm{~cm}, 60.5$ to $72 \mathrm{~cm}$, 71 to $82.2 \mathrm{~cm}$ and 0.85 to 0.86 respectively from nine to twelve year old subjects.

A cross sectional study conducted on Chinese school aged 6-12 year children found that waist circumference increased with age in both boys and girls. Waist circumference has been identified as a valuable predictor of CVD risk in children [11].

A cross sectional observational study was undertaken at ICDS centres to determine their nutritional status using MUAC. Results revealed that mean MUAC among the subjects increased in all age groups [12].

Table 9. Skin fold thickness measurements of subjects $(\mathrm{n}=63)$

\begin{tabular}{|c|c|c|c|c|c|c|}
\hline $\begin{array}{c}\text { Age } \\
\text { (inyears) }\end{array}$ & $\mathbf{n}$ & $\begin{array}{c}\text { Triceps } \\
(\mathbf{m m}) \\
\text { Mean } \\
\pm \text { SD }\end{array}$ & $\begin{array}{c}\text { Biceps } \\
(\mathbf{m m}) \\
\text { Mean } \\
\pm \text { SD }\end{array}$ & $\begin{array}{c}\text { Sub } \\
\text { scapular } \\
(\mathbf{m m}) \\
\text { Mean } \\
\pm \text { SD }\end{array}$ & $\begin{array}{c}\text { Suprailiac } \\
(\mathbf{m m}) \\
\text { Mean } \pm \text { SD }\end{array}$ & $\begin{array}{c}\text { SSFT } \\
\text { Mean } \\
\pm \text { SD }\end{array}$ \\
\hline 9 & 13 & $\begin{array}{c}11.1 \pm \\
5.5\end{array}$ & $6.7 \pm 3.0$ & $8.4 \pm 4.6$ & $9.2 \pm 5.3$ & $\begin{array}{c}35.5 \\
\pm 17.7\end{array}$ \\
\hline 10 & 13 & $\begin{array}{c}12.6 \\
\pm 4.9\end{array}$ & $7.5 \pm 4.3$ & $10.3 \pm 5.6$ & $10.4 \pm 7.5$ & $\begin{array}{c}40.8 \\
\pm 21.8\end{array}$ \\
\hline 11 & 19 & $\begin{array}{c}11.9 \\
\pm 3.6\end{array}$ & $6.6 \pm 2.1$ & $9.7 \pm 4.1$ & $12.5 \pm 3.5$ & $\begin{array}{c}37.3 \\
\pm 22.7\end{array}$ \\
\hline 12 & 18 & $\begin{array}{c}14.2 \pm \\
5.4\end{array}$ & $7.4 \pm 2.8$ & $2.9 \pm 6.3$ & $12.1 \pm 6.0$ & $\begin{array}{c}46.6 \\
\pm 19.4\end{array}$ \\
\hline
\end{tabular}

${ }^{\star}$ SSFT- Sum of Skin Fold Thickness

The skin fold thickness measurements of subjects were taken at four sites, it was found that there was increase in value from 11.1 to $14.2 \mathrm{~mm}$ for Triceps and even in subscapular and suprailiac measurements increase from 8.4 to $12.9 \mathrm{~mm}$ and 9.2 to $12.1 \mathrm{~mm}$ respectively, the Biceps measurements increased in ten and twelve year old school age except in eleven year. It has been reported that skin fold thickness of school children aged 6-18 years showed a significant increase at all ages and there is good association between MUAC and SSFT with age in school children [9].

Table 10. Body fat percentage of subjects by deurenberg predictive equation $(n=63)$

\begin{tabular}{|c|c|c|}
\hline Age (in years) & $\mathbf{N}$ & Percent Body fat ${ }^{*}$ Mean \pm SD \\
\hline 9 & 13 & $18 \pm 5.8$ \\
\hline 10 & 13 & $17.6 \pm 5.9$ \\
\hline 11 & 19 & $16.4 \pm 4.2$ \\
\hline 12 & 18 & $19.2 \pm 5.3$ \\
\hline
\end{tabular}

${ }^{\star}$ Deurenberg Predictive equation (1991)

The body fat per cent of the subjects was computed using Deurenberg Equation (1991). It was evident from the table that the fat ranged from 16.4 to 19.2 per cent respectively. The least value was for the eleven year olds and the highest for the twelve year olds. 
Table 11. Body fat percentage of subjects by mcardle equation $(n=63)$

\begin{tabular}{|c|c|c|}
\hline Age(in years) & $\mathbf{N}$ & Percent Body fat $^{*}$ Mean \pm SD \\
\hline 9 & 13 & $14.8 \pm 4.3$ \\
\hline 10 & 13 & $16.3 \pm 4.4$ \\
\hline 11 & 19 & $15.7 \pm 3.1$ \\
\hline 12 & 18 & $17.9 \pm 4.8$ \\
\hline
\end{tabular}

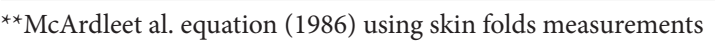

The body fat per cent of the subjects was computed using Mc Ardle et al. (1986) Equation. As evident from the table the fat per cent ranged from 14.8 to 17.9 per cent respectively. The least value was for the eleven year olds and the highest for the twelve year olds.

Table 12. Mean body fat percentage of subjects bygender $(n=63)$

\begin{tabular}{|c|c|c|}
\hline Gender & $\begin{array}{c}\text { Percent Body fat } \\
\text { (Deurenberg equation) }\end{array}$ & $\begin{array}{c}\text { Percent Body fat } \\
\text { (McArdle equation) }\end{array}$ \\
\hline Boys & 16.2 & 15.9 \\
Girls & 20.4 & 16.8 \\
\hline
\end{tabular}

The above table shows the body fat percentage of the subjects according to gender by Deurenberg equation and McArdle et al predictive equation.

\subsection{Biochemical Data of Subjects}

The Biochemical parameters namely TC, LDL, HDL, TG levels are summarized in the Table 13.

On studying the lipid profile of the subjects it was found that the Total Cholesterol ranges from 173-190 $\mathrm{mg} / \mathrm{dl}$, Low Density lipoprotein Cholesterol level ranges from 100-112 mg/dl, High Density lipoprotein level ranges from 47-52 mg/dl, Triglyceride level ranges from $74-106 \mathrm{mg} / \mathrm{dl}$.

Table 13. Lipid profile of subjects $(n=63)$

\begin{tabular}{|c|c|c|c|c|}
\hline $\begin{array}{c}\text { Age } \\
\text { (in years) }\end{array}$ & $\mathbf{N}$ & $\begin{array}{c}\text { LDL(mg/dl) } \\
\text { Mean } \pm \text { SD }\end{array}$ & $\begin{array}{c}\text { HDL(mg/dl) } \\
\text { Mean } \pm \text { SD }\end{array}$ & $\begin{array}{c}\text { TG(mg/dl) } \\
\text { Mean } \pm \text { SD }\end{array}$ \\
\hline 9 & $188.3 \pm 33.23$ & $112.6 \pm 27.9$ & $49.8 \pm 9.8$ & $74.7 \pm 19.6$ \\
\hline 10 & $186.1 \pm 32.9$ & $110.1 \pm 23.5$ & $52.1 \pm 9.4$ & $103.3 \pm 48.2$ \\
\hline 11 & $190.8 \pm 27.9$ & $112.5 \pm 21.7$ & $49.4 \pm 9.4$ & $106.5 \pm 45.6$ \\
\hline 12 & $173.1 \pm 35.2$ & $100.3 \pm 26.9$ & $47.8 \pm 7.2$ & $100.1 \pm 59.5$ \\
\hline
\end{tabular}

TC-total cholesterol, LDL-low density lipoprotein cholesterol, HDL-high density lipoprotein cholesterol, TG-triglyceride

Abnormal serum concentrations of lipids such as TC and LDL are strongly associated with early atherosclerotic lesions [13]. One of the most notable components of atherosclerotic plaque is cholesterol, both in the cells and within the matrix of the arterial tissues [5].

\subsection{Dietary Intake Pattern of Subjects}

The nutrient intake pattern of the subjects namely macronutrient and fibre intake and its comparison with RDA are presented in the Table 14.

Table 14. Mean nutrient intake of subjects $(n=63)$

\begin{tabular}{|c|c|c|c|c|c|}
\hline Gender & $\begin{array}{c}\text { Energy } \\
(\mathbf{k c a l}) \text { Mean } \\
\mathbf{S S D}\end{array}$ & $\begin{array}{c}\text { Protein }(\mathrm{g}) \\
\text { Mean } \\
\pm \mathrm{SD}\end{array}$ & $\begin{array}{c}\text { CHO }(\mathrm{g}) \\
\text { Mean } \\
\pm \mathrm{SD}\end{array}$ & $\begin{array}{c}\text { Fibre }(\mathrm{g}) \\
\text { Mean } \\
\pm \mathrm{SD}\end{array}$ & $\begin{array}{c}\text { Fat }(\mathrm{g}) \\
\text { Mean } \\
\pm \mathrm{SD}\end{array}$ \\
\hline Boys & $1792.7 \pm 340.5$ & $49.2 \pm 10.7$ & $281.7 \pm 63.6$ & $3.9 \pm 1.5$ & $53.2 \pm 10.2$ \\
Girls & $1678.2 \pm 208.1$ & $43.6 \pm 7.7$ & $263.2 \pm 39.7$ & $3.9 \pm 1.4$ & $51.0 \pm 8.9$ \\
\hline
\end{tabular}

The above table summarises the nutrient intake pattern of the subjects by gender. The macronutrient intake pattern of the subjects was higher among boys than girls. Energy and carbohydrate intake were gradually escalating in boys of nine to twelve year old. It was evident from the above table that the energy intake was significantly low from the recommended intake among the subjects, with the most significant difference in ten year old subjects. Even though the energy intake of the subjects is significantly lower from the RDA, protein and fat intakes were much higher among the study subjects.

\subsection{Correlation of Body Composition and Nutritional Status of Subject}

On studying Pearson's correlation of anthropometric parameters with per cent body fat it was evident that there exists a positive correlation $(\mathrm{P}<.01)$ between all the anthropometric parameters and per cent body fat, indicating that there is an increase in the anthropometric dimensions of an individual the per cent body fat also increases proportionately.

A case study conducted on healthy Nigerian school girls aged 9-14 years, to assess their body composition found that correlation coefficients between BMI and other anthropometric variables were significant. BMI correlated more strongly with percent body fat and fat free mass $(\mathrm{P}<.05)$. There was a strong correlation between BMI and body weight $(\mathrm{P}<.05)$, sum of SFT correlated more strongly with percent body fat and fat free mass $(\mathrm{P}<.05)$ [14] (Table 15). 
Table 15. Correlation of anthropometric parameters with body fat

\begin{tabular}{|c|c|c|}
\hline Parameters & $\begin{array}{c}\text { Percent Body fat } \\
\text { (Deurenberg equation) } \mathbf{P} \\
\text { value }\end{array}$ & $\begin{array}{c}\text { Percent Body fat } \\
\text { (McArdle equation) P } \\
\text { value }\end{array}$ \\
\hline Weight $(\mathrm{kg})$ & $0.795^{* *}$ & $0.788^{* *}$ \\
\hline Height $(\mathrm{cm})$ & $0.336^{*}$ & $0.377^{*}$ \\
\hline MAC $(\mathrm{cm})$ & $0.831^{* *}$ & $0.843^{* *}$ \\
\hline Waist $(\mathrm{cm})$ & $0.823^{* *}$ & $0.880^{* *}$ \\
\hline Hip $(\mathrm{cm})$ & $0.850^{* *}$ & $0.826^{* *}$ \\
\hline WHR & $0.352^{* *}$ & $0.549^{*}$ \\
\hline BMI $\left(\mathrm{kg} / \mathrm{m}^{2}\right)$ & $0.928^{* *}$ & $0.889^{* *}$ \\
\hline $\mathrm{SSFT}$ & $0.845^{* *}$ & $0.978^{* *}$ \\
\hline
\end{tabular}

${ }^{* *}$ Correlation is significant at.01level ${ }^{*}$ SSFT- sum of skin fold thickness, ${ }^{*}$ Correlation is significant at 0.01 level, ${ }^{*}$ Correlation is significant at 0.05level

Table 16. Pearson's correlations of anthropometric parameters with SSFT

\begin{tabular}{|c|c|}
\hline Parameters & SSFTP value \\
\hline Age $($ years $)$ & $0.274^{*}$ \\
\hline Weight $(\mathrm{kg})$ & $0.773^{* *}$ \\
\hline Height $(\mathrm{cm})$ & $0.347^{* *}$ \\
\hline MAC $(\mathrm{cm})$ & $0.821^{* *}$ \\
\hline Waist $(\mathrm{cm})$ & $0.876^{* *}$ \\
\hline Hip $(\mathrm{cm})$ & $0.727^{* *}$ \\
\hline WHR & $0.567^{* *}$ \\
\hline BMI $\left(\mathrm{kg} / \mathrm{m}^{2}\right)$ & $0.894^{* *}$ \\
\hline${ }^{*}$ SSFT- sum of skin fold thickness, ${ }^{* *}$ Correlation is significant at \\
0.01level, ${ }^{*}$ Correlation is significant at 0.05 level
\end{tabular}

On studying, Peawrson's correlation between SSFT and anthropometric parameters, it was evident that there exists a positive correlation $(\mathrm{P}<.01)$ between all the anthropometric parameters indicating increased subcutaneous fat (Table 16). Studies conducted on Nigerian school children aged 9-14 years reported that, SFT values indicating different extents of subcutaneous fat deposition and different distribution patterns. It was observed that sum of SFT correlated highly with all the anthropometric parameters [14].

The Table 17 clearly indicates that elevation of body fat composition lowers the level of HDL cholesterol and promotes hyperinsulinemia and hyper triglyciedemia.

Pearson's correlation coefficient between per cent body fat and biochemical parameters showed a statistically significant $(\mathrm{P}<.01) \quad$ correlation between serum insulin and triglycerides. This is indicative that with increase in per cent body fat there are elevations both in insulin and triglycerides. In the case of HDL cholesterol although there existed a negative correlation it was not statistically significant using both the equations. Mcardle et al equation computation had a statistically significant difference while it was not so in the case of the Deurenberg equation.

Table 17. Pearson's correlation between biochemical parameters and body composition

\begin{tabular}{|c|c|c|}
\hline Parameters & $\begin{array}{c}\text { Percent Body } \\
\text { fat (Deurenberg } \\
\text { equation)P value }\end{array}$ & $\begin{array}{c}\text { Percent Body } \\
\text { fat (McArdle } \\
\text { equation)P value }\end{array}$ \\
\hline Insulin(m $/ \mathrm{L})$ & $0.598^{* *}$ & $0.567^{* *}$ \\
\hline FBS(mg/dL) & -0.043 & -0.031 \\
\hline Total cholesterol(mg/dL) & 0.039 & 0.065 \\
\hline HDL $(\mathrm{mg} / \mathrm{dL})$ & -0.237 & $-0.327^{* *}$ \\
\hline LDL $(\mathrm{mg} / \mathrm{dL})$ & 0.100 & 0.140 \\
\hline VLDL $(\mathrm{mg} / \mathrm{dL})$ & $0.342^{* *}$ & $0.418^{* *}$ \\
\hline Triglyceride(mg/dL) & $0.311^{*}$ & $0.417^{* *}$ \\
\hline
\end{tabular}

On studying the Pearson's correlation coefficient between BMI and the biochemical parameters it was observed that there exist a positive correlation between insulin and triglycerides and a negative correlation with HDL cholesterol (Table 18). Hakeem et al [15] reported that there was an evidence that body composition in children may be more closely correlated to TC levels. BMI and blood lipid profiles are important criteria for CVD's [16].Therefore evaluation of relationships between anthropometric parameters and lipid levels will identify the risk level for CVD in children. It was found that BMI was significantly correlated with serum TG [17].

Table 18. Correlation of biochemical parameters with body mass index

\begin{tabular}{|c|c|}
\hline Parameters & BMIP value \\
\hline Insulin $(\mathrm{m} \mu / \mathrm{L})$ & $0.602^{* *}$ \\
\hline FBS $(\mathrm{mg} / \mathrm{dL})$ & -0.011 \\
\hline Total cholesterol $(\mathrm{mg} / \mathrm{dL})$ & 0.003 \\
\hline HDL $(\mathrm{mg} / \mathrm{dL})$ & $-0.254^{* *}$ \\
\hline $\mathrm{LDL}(\mathrm{mg} / \mathrm{dL})$ & 0.056 \\
\hline VLDL $(\mathrm{mg} / \mathrm{dL})$ & $0.381^{* *}$ \\
\hline Triglyceride $(\mathrm{mg} / \mathrm{dL})$ & $0.386^{* *}$ \\
\hline
\end{tabular}

"Correlation is significant at 0.01 level 
Table 19. Correlation of nutrient intake with body fat

\begin{tabular}{|c|c|c|}
\hline Nutrient intake & $\begin{array}{c}\text { Per cent Body } \\
\text { fat(Deurenberg } \\
\text { equation) P value }\end{array}$ & $\begin{array}{c}\text { Per cent Body fat } \\
\text { (McArdle equation) P } \\
\text { value }\end{array}$ \\
\hline Energy(kcal) & 0.021 & 0.108 \\
\hline Protein(g) & -0.090 & 0.032 \\
\hline Fat(g) & -0.028 & -0.071 \\
\hline Carbohydrate(g) & 0.052 & 0.166 \\
\hline Fibre(g) & 0.121 & 0.155 \\
\hline Cholesterol(mg/dl) & -0.179 & -0.138 \\
\hline
\end{tabular}

On studying the Pearson's correlation of nutrient intake with per cent body fat and fat mass, it was found that there was no significant correlation between these parameters (Table 19).

Studies conducted on preadolescent children aged 9-11 years examined the relationship between diet and body fatness. It was found that there was an evidence of any interaction between energy intake and per cent body fat. Also protein intake was not related to body fat. Even carbohydrate was inversely correlated. In contrary to the present study, the above study proved that total dietary fat significantly and positively correlated with per cent body fat [18].

\section{Conclusion}

The mean values for height, weight, BMI and body composition parameters of 63 subjects were used and body fat percentage were computed using prediction equations such as Deurenberg equation (1991) and McArdle et al. equation (1986). Computation of per cent body fat from these equations gives an insight into the body composition which can be considered an indicative predictor of lifestyle diseases.

\section{References}

1. Chang H. S., and Kim M. J., "Study on dietary behaviour of elementary school student in Chungnam area according to the school food service type, gender and grade", Korean Journal of Community Nutrition, vol. 11, p. 608-617, 2006.

2. Eun-Suil C., Na Ri Shin., EunIm J., Hae R. P., Hong M. L., and Kyung H. S., "Study on nutrition knowledge and dietary behaviour of elementary school children in Seoul", Korean Journal of Community Nutrition, vol. 2, p. 308-316, 2008.
3. Brambilla P., Manzoni P., Sironi S., Simone P., Del Maschio A., Di Natale B., and Chiumello G., "Peripheral and abdominal adiposity in childhood obesity", International journal of obesity related Metabolism Disorder, vol. 18, p. 795-800, 1994.

4. Malina R. H., "Regional Body composition", Human kinetics, p. 217-255, 1985.

5. Deurenberg P., Weststrate J. A., and Seidell J. C., "BMI as a measurement of body fatness, age, gender specific prediction formula", British Journal of Nutrition, vol. 65, p. 105-114, 1991.

6. McArdle W. D., Exercise Physiology, Lea and Febiger, Philadelphia, 1986.

7. Kosulwat V., "The Nutrition and health transition in Thailand", public health nutrition, vol. 5, p. 183-189, 2003.

8. Shetty P. S., "Nutrition transition in India", Public health Nutrition, vol. 5, p. 175-182, 2002.

9. Musaiger A. O., "Profile of body composition of school children 6-18 year in Baharian", International Journal of Obesity, vol. 24, p. 1093-1096, 2000.

10. Shah C., Diwan J., Rao P., Bhabhor M., Gokhle P., and Mehta H., "Assessment of obesity in school children", Calicut Medical Journal, vol. 6(3), p. 2, 2008.

11. Ailingliu., "Dynamic analysis on prevalence of obesity and overweight school age children and adolescents in recent 15years in China", Korean Journal of Clinical Nutrition, vol. 5, p. 103-108, 2010.

12. Mandal G., "Diet Composition and body composition in preschool children", American Journal of Clinical Nutrition, vol. 8, p. 55-59, 2009.

13. Berenson G. S., Srinivasan S. R., Wattigney W. A., Bao W., Newman W. P., and Tracy R. E., "Association between multiple CVD risk factors in children", Nutrition England Journal of Medicine, vol. 338, p. 650-656, 1998.

14. Abiodun H. C., "Energy intake, anthropometry and body composition of Nigerian girls", British journal of Nutrition, vol. 77, p. 497-509, 1997.

15. Hakeem R., Thomas J., Badruddin S. H., "Urbanisation and coronary heart disease risk factors in South Asian Children", Journal of Pakistan medical Association, vol. 51, p. 22-28, 2001.

16. Higgen et al., "Central over weight and obesity in British youth aged 10-16 years", Biomedical Journal, vol. 326, 2001.

17. William P., Going S. B., Lohman T. G., Harsha D. W., Srinivasan S. R., Webber L. S., and Berenson G. S., "Body Fatness and risk of elevated blood pressure and total cholesterol", American Journal of Public Health, vol. 82, p. 358363, 1996.

18. Jeannie M., "Relationship between diet composition and body fatness with adjustment for resting energy expenditure and physical activity in preadolescent children", American journal of Clinical Nutrition, vol. 58, p. 21-28, 1993. 